\title{
The influence of Typha Australis as an insulation panel on the thermal performance of building
}

\author{
Labouda Ba ${ }^{1,2 \& 3^{*}}$, Ikram EL ABBASSI', Cheikh S.E Kane ${ }^{3}$, A-Moumen Darcherif ${ }^{1}$, Mamoudou Ndongo ${ }^{3}$ \\ ${ }^{1}$ Laboratoire de Quartz, Université de Cergy-Pontoise (France) \\ ${ }^{2}$ Laboratoire de Recherche en Eco-innovation Industrielle et Energétique, ECAM-EPMI,13 bd de l'hautil 95092,Cergy-Pontoise (France) \\ ${ }^{3}$ Unité de recherche appliquée sur les énergies renouvelables, Université de Nouakchott Al Asriya, Nouakchott (Mauritanie) \\ Laboratoire de Mécanique et Matériaux du Génie Civil, Université de Cergy-Pontoise (France)
}

\begin{abstract}
Typha Australis is a plant that grows abundantly in fresh water. The proliferation of this plant causes health problems, so several measures have been taken to eradicate this problem such as: cutting the plant, coal production. So this article is about the valorisation of this plant as a bio-based material in order to solve the energy problem in the building. In this study, clay was used as a binder with a given percentage. The mixture of clay and Typha was used as an insulation panel and a comparison was made with a conventional habitat without an insulation panel. A dynamic thermal simulation was performed on TRNSYS to evaluate the influence of the use of this insulation panel on the energy consumption in the building. The results of the comparison showed that the use of this insulation panel, which is a mixture of clay and Typha Australis, reduced the energy requirement by $23 \%$, which is a satisfactory result.
\end{abstract}

\section{Introduction}

In recent years, we have witnessed environmental scourges that impact human well-being and health. As a result, the use of high-performance building materials and new technologies in the building sector has been adopted with the development of materials based on renewable plant resources in order to address these environmental problems [1]. These renewable vegetable fibres have low environmental impacts because they are less energy consuming (six times less energy consuming than glass fibres and twelve times less than carbon fibres) and generally have low densities [2]. The use of these fibres as a building material is a solution to overcome the problem of thermal comfort in the building and also to optimize the energy requirement. This optimization could be carried out through the thermal performance of these bio-based building materials. Indeed, several studies have been conducted to evaluate the thermal performance of these bio-based building materials $[3,4,5]$. For example, materials have been studied such as mixing peanut shells and plaster, peanut shells allow materials to have good thermal stability compared to plaster alone for wall and roof coverings [3], there are also studies that have shown thermomechanical characteristics of cork or lightweight concrete based on olive residue, providing ideas that prove that cork is a suitable insulating material for a wall and the heating plate is used to determine the thermal properties of mixtures. [4, 5].

These materials being spread in several countries of the world. In our study we chose to study the valorisation of Typha Australis which is a plant of West Africa which grows in profusion in the Senegal River valley. Indeed,

\footnotetext{
*Corresponding author: laboudaa@gmail.com
}

recent studies have shown that this fiber could be used in construction [6-7]. In this article we will study the impact of the use of Typha Australis on the energy requirement of a building. This study will be done using Trnsys software, a dynamic thermal simulation software that has been used by several researchers around the world to evaluate the thermal effects of buildings [8]. The binder used in this article is clay, because it is a local material and with almost no transformation, resulting in a lower carbon impact. The next part of this article will show the methodology and modelling performed for the simulation.

\section{Method and modelling}

Two habitats were studied, the first is a conventional habitat without insulation panel which will be named in the following article by building $\left(\mathrm{H}_{\text {no-ip }}\right)$ and the second is a conventional habitat but with an insulation panel which will be named by Building $\left(\mathrm{H}_{\mathrm{ip}}\right)$. the insulation panel used is the mixture of clay and Typha Australis which will be inserted into the walls of this conventional habitat as well as among its compositions.

\subsection{Building description}

The two habitats have the same geometric shape which is $4 m * 5 m * 3 m$ similar to offices with a wooden door and double glazed windows and their dimensions are given in Table 1. The location site is Nouakchott (the climate of the site is given by Meteonorm). 
Table 1. Building size

\begin{tabular}{|c|c|c|}
\hline & Length $(\mathrm{m})$ & Width $(\mathrm{m})$ \\
\hline $\begin{array}{c}\text { Walls and } \\
\text { roof }\end{array}$ & 5 & 4 \\
\hline Door & 2.1 & 0.8 \\
\hline Window & 1 & 0.8 \\
\hline
\end{tabular}

\subsection{Thermo-physical characteristics of the insulation panel}

The thermo-physical characterizations of the insulation panel have been collected from the literature [6], the mixture is composed of $22.9 \%$ Typha Australis and the data are presented in Table 2:

Table 2. characteristics of the clay mixture and Typha Australis

\begin{tabular}{|c|c|}
\hline $\begin{array}{c}\text { Effusivity (E) } \\
\mathrm{J} \cdot \mathrm{m}^{2} \cdot \mathrm{K}^{-1} \cdot \mathrm{s}^{-1 / 2}\end{array}$ & 242 \\
\hline $\begin{array}{c}\text { Conductivity }(\lambda) \\
\mathrm{W} \cdot \mathrm{m}^{-1} \cdot \mathrm{K}^{-1}\end{array}$ & 0.127 \\
\hline Mass heat $(\mathrm{Cp}) \mathrm{KJ} / \mathrm{K}$ & 461 \\
\hline Density $(\rho) \mathrm{Kg} / \mathrm{m}^{3}$ & 1000 \\
\hline
\end{tabular}

As the thermo-physical conductivity is relatively low, this mixture could be considered as an insulating.

\subsection{Composition of building $\left(\mathrm{H}_{\text {no-ip }}\right)$}

Building (Hno-ip) is the so-called conventional habitat, it does not contain an insulation panel, the composition of the walls and roof of this habitat are shown in Table 3 and Table 4 respectively.

Table 3. Composition of wall (Hno-ip)

\begin{tabular}{|c|c|c|}
\hline Wall & Compositions & $\begin{array}{c}\text { Thickness } \\
(\mathrm{m})\end{array}$ \\
\hline \multirow{4}{*}{ Int wall } & Cement mortar & 0,03 \\
\cline { 2 - 3 } & Parpaing & 0,15 \\
\cline { 2 - 3 } & Plaster & $0 ., 02$ \\
\hline \multirow{4}{*}{ Out wall } & Mortar cement & 0,03 \\
\cline { 2 - 3 } & Plaster & 0,02 \\
\hline
\end{tabular}

Table 4. Composition of roof (Hno-ip)

\begin{tabular}{|c|c|}
\hline $\begin{array}{l}\text { Composition of } \\
\text { roof for }\end{array}$ & $\begin{array}{c}\text { Thickness } \\
(\mathrm{m})\end{array}$ \\
\hline Cement Mortar & 0,1 \\
\hline Parpaing & 0,15 \\
\hline Cement Mortar & 0,1 \\
\hline Plaster & 0,05 \\
\hline
\end{tabular}

\subsection{Composition of building $\left(\mathrm{H}_{\mathrm{ip}}\right)$}

Building $\mathrm{H}_{\mathrm{ip}}$ is the building consisting of an insulation panel. Cement mortar in conventional building is replaced by the mixture of Typha Australis and clay (insulation board). The table 5 and Table 6 represent the composition of this building.

Table 5. Composition of wall $\left(\mathrm{H}_{\mathrm{ip}}\right)$

\begin{tabular}{|c|c|c|}
\hline Wall & Compositions & Thickness (m) \\
\hline \multirow{4}{*}{ Int wall } & $\begin{array}{c}\text { Mixture of Typha } \\
\text { Australis and clay }\end{array}$ & 0,03 \\
\cline { 2 - 3 } & Parpaing & 0,15 \\
\cline { 2 - 3 } & Plaster & $0 ., 02$ \\
\hline \multirow{2}{*}{ Out wall } & $\begin{array}{l}\text { Mixture of Typha } \\
\text { Australis and clay }\end{array}$ & 0,03 \\
\cline { 2 - 3 } & Plaster & 0,02 \\
\hline
\end{tabular}

Table 6. Composition of roof $\left(\mathrm{H}_{\mathrm{ip}}\right)$

\begin{tabular}{|c|c|}
\hline $\begin{array}{c}\text { Composition of roof } \\
\text { for }\end{array}$ & Thickness (m) \\
\hline $\begin{array}{c}\text { Mixture of Typha } \\
\text { Australis and clay }\end{array}$ & 0,1 \\
\hline Parpaing & 0,15 \\
\hline $\begin{array}{c}\text { Mixture of Typha } \\
\text { Australis and clay }\end{array}$ & 0,1 \\
\hline Plaster & 0,05 \\
\hline
\end{tabular}




\subsection{Modelling}

The simulation was carried out on TRNSYS which uses the Fortran programming language, the habitat characteristics were implemented in the software. The simulation was carried out over a full year, i.e. over 8760 hours. The set temperature has been set at $25^{\circ} \mathrm{C}$. This is the difference between the maximum and minimum ambient temperature $\left(\max 40^{\circ} \mathrm{C}\right.$ and $\min 15^{\circ} \mathrm{C}$ ). The energy system (air conditioning) is used when the office is busy, i.e. Monday to Friday from $8 \mathrm{am}$ to $6 \mathrm{pm}$.

\subsection{Mathematical Model}

The Trnsys "type 56" module was used to simulate the transfer phenomena in the building [9]. The walls are governed by the three modes of transfer: conduction (in the wall), convection (between the wall and the fluid 'air') and short and long wavelength radiation.

The exchange by conduction on TRNSYS is the Z-transform method which is more efficient than the finite difference method [10].

Exchange by conduction on the walls [11]:

$\varphi_{c e}(t)=-\sum_{i=0}^{N a} a_{i} T_{s e}(t-i \Delta t)+\sum_{i=0}^{N b} b_{i} T_{s i}(t-i \Delta t)-\sum_{i=0}^{N d} d_{i} \varphi_{c}$

$\varphi_{c i}(t)=-\sum_{i=0}^{N a} b_{i} T_{s e}(t-i \Delta t)+\sum_{i=0}^{N b} c_{i} T_{s i}(t-i \Delta t)-\sum_{i=0}^{N d} d_{i} \varphi_{c}$

$\varphi_{c}$ : conductive flux density $\left(\mathrm{W} / \mathrm{m}^{2}\right)$

$a_{i}, b_{i}, c_{i}$ : Coefficients of the Z-transform of functions transfer rates for surface temperatures $\left(\mathrm{W} / \mathrm{m}^{2} \mathrm{~K}\right)$

$d_{i}$ : Coefficients of the Z-transform of transfer functions related to flow densities

$N a, N b, N d$ : number of coefficients $a_{i}, b_{i}, C_{i}$ and $d_{i}$

$\Delta t$ : simulation step

$T_{\text {se }}(t-i \Delta t)$ : Temperature of the outer surface of the wall at $(t-i \Delta t)(\mathrm{K})$

$T_{s i}(t-i \Delta t)$ : Temperature of the inner surface of the wall at $(t-i \Delta t)(\mathrm{K})$

Exchange by conduction on the glazing [11]:

Since the glazing is considered to be inertial, the equation that models the conduction exchange is in steady state.

$$
\varphi_{c}=K\left(T_{s i}-T_{s e}\right)
$$

$\varphi_{c}$ : conductive flux density for glazing

$\mathrm{K}$ : Conductivity 'surface - surface' of the glass wall (W/ $\left.\mathrm{m}^{2} \mathrm{~K}\right)$

Convection exchange

$$
\begin{aligned}
\varphi_{c o n v, e} & =h_{c e}\left(T_{s e}-T_{e}\right) \\
\varphi_{c o n v, i} & =h_{c i}\left(T_{s i}-T_{i}\right)
\end{aligned}
$$

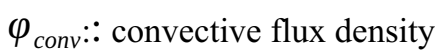

$T_{e}$ and $T_{i}$ : Temperature of the outdoor and indoor environment

$h_{c e}, h_{c i}$ : Coefficients of convection on the outer and inner sides

Radiation exchange

$$
\varphi_{\text {rde }}=\varphi_{C L O e}+\varphi_{G L O e}
$$

$\varphi_{\text {rde }}:$ radiative flux density

$\varphi_{C L O}:$ Short wavelength radiative flux density

$\varphi_{G L O}$ :Long wavelength radiative flux density

$$
\varphi_{G L O e}=h_{r, c}\left(T_{s e}-T_{c}\right)+h_{r, e}\left(T_{s e}-T_{e}\right)
$$

$h_{r, c}$ : Coefficient of GLO radiative exchange with the environment

$h_{r, e}$ : GLO radiation exchange coefficient with the celestial vault

Short wavelength radiative exchanges, the data are derived from meteorological data.

The heat transfer balance in a room (the building) [11]:

$\sum_{i=0}^{N a} S_{i} h_{c i}\left(T_{s i}-T_{i}\right)+m_{a}^{\prime} c_{a}\left(T_{a}-T_{i}\right)+A_{p}=\rho_{a} c_{a} V \frac{d T_{i}}{d t}$

$m_{a}$ :Air flow rate into the zone $(\mathrm{kg} / \mathrm{s})$

$\rho_{a}$ :Air density (assumed to be constant) $\left(\mathrm{kg} / \mathrm{m}^{3}\right)$

$\mathrm{V}$ : volume $\left(\mathrm{m}^{3}\right)$

$A_{p}:$ Internal convective gain $(\mathrm{W})$

$T_{a}$ : Air temperature $(\mathrm{K})$

\subsection{Numerical simulation model}

The following figure represents the numerical model of the simulation. The inputs and outputs are shown.

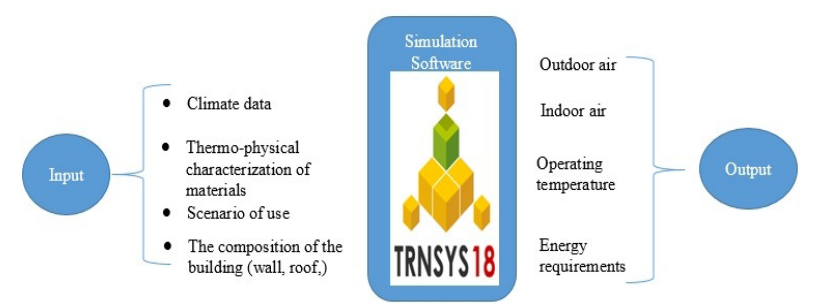

Fig.1.Numerical model 


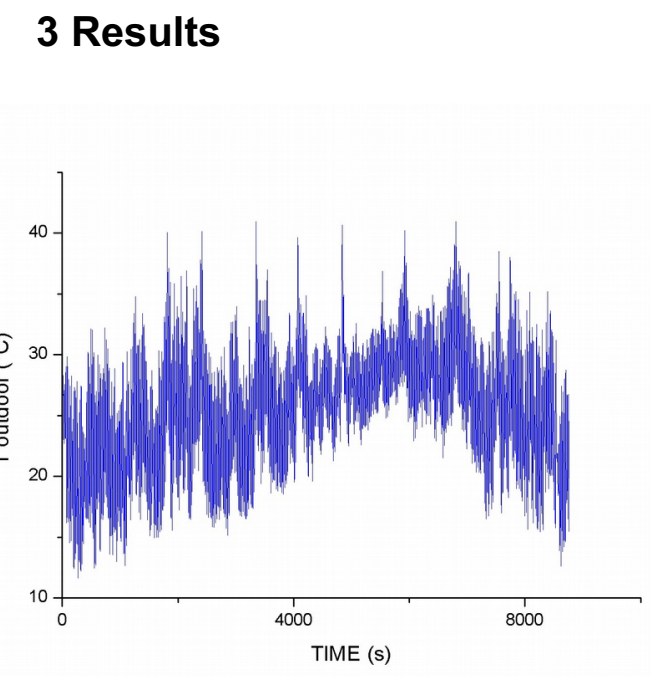

Fig.2.Outdoor temperature

In this section we discuss the results of the simulations in order to evaluate the rate of reduction in energy demand by substituting conventional building by a building with an insulation panel. Indeed, this rate is assessed by comparing these two buildings.

Figure 2, Figure 3 and Figure 4 represent the outdoor, Air and operating temperature of the building, we can notice that the operating temperature is close to the indoor temperature and that the latter is equal to the indoor temperature if the air conditioning is not used otherwise it is equal to the set temperature and that the outdoor temperature fluctuates between $15^{\circ} \mathrm{C}$ and $40^{\circ} \mathrm{C}$.

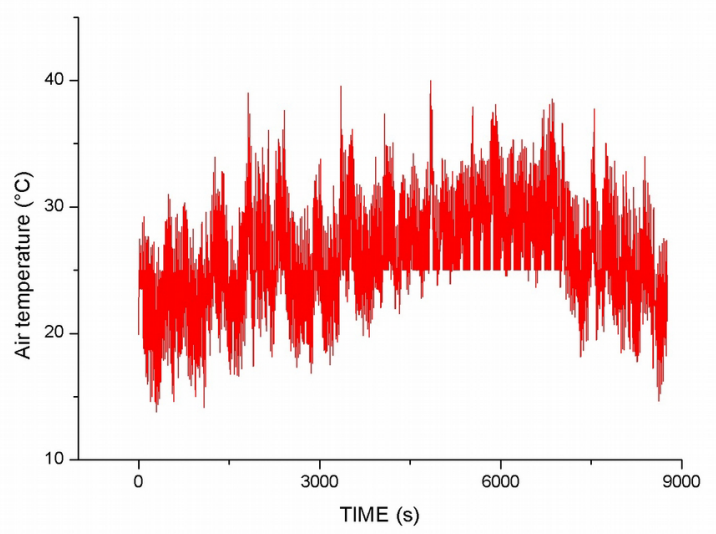

Fig. 3. Air temperature

Fig. 4. Operating temperature

Figure 5 represents the energy consumption in order to keep the set temperature when it is imposed, this consumption is zero when the air conditioning is not used.

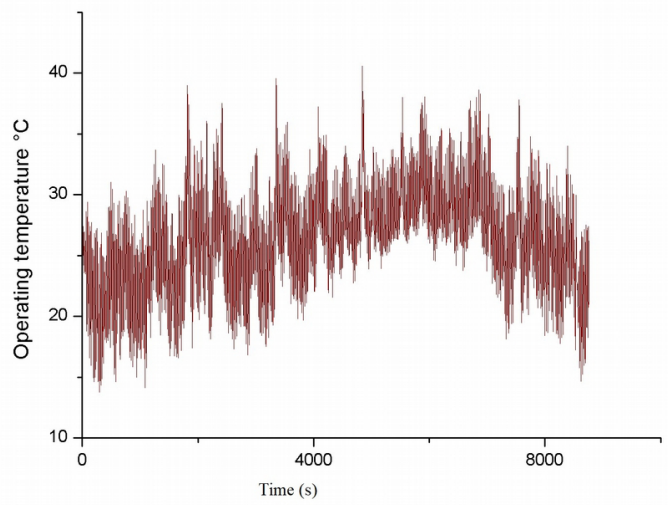

The curve in Figure 6 shows the energy requirement for air conditioning when the building is occupied and the temperature is set at $25^{\circ} \mathrm{C}$.

The numerical simulation on Trnsys, provided us with the annual air-conditioning requirement which is $5903.2 \mathrm{kwh}$ for the building without insulation panel and $4532.06 \mathrm{kwh}$ for the building with insulation panel, hence a $23 \%$ reduction in energy consumption.

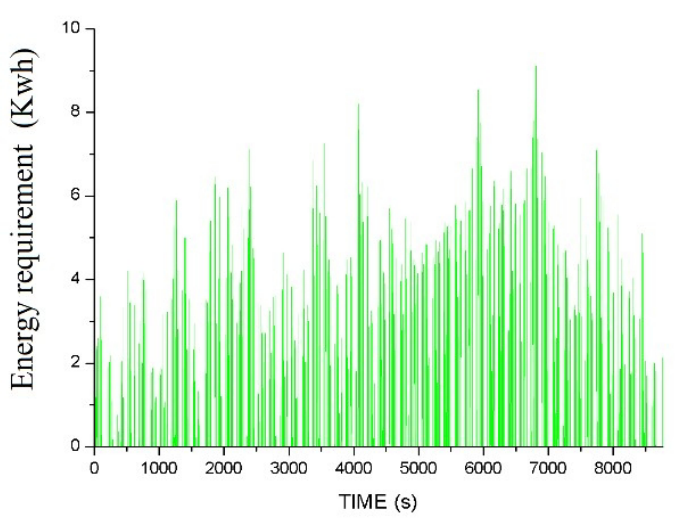

Fig.5.Energy requirement 


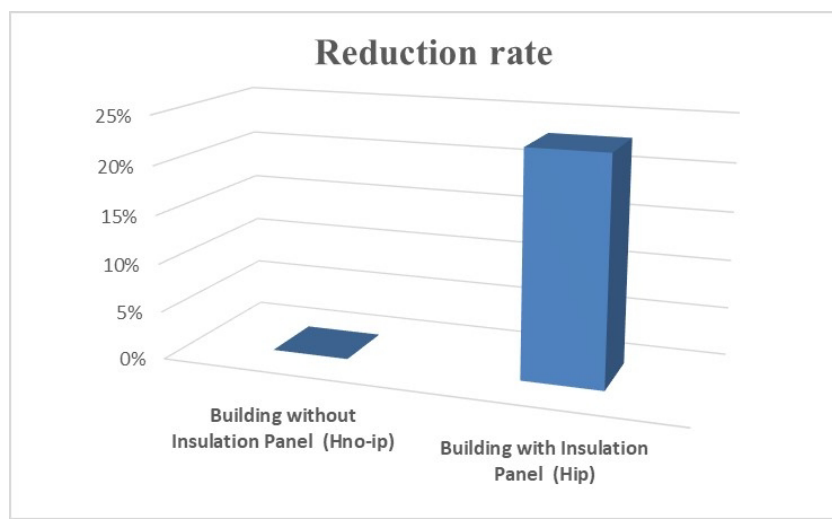

Fig.6.Reduction rate

This result allows us to state that, given the low thermal conductivity of the clay/Typha Australis mixture, the building's energy needs could be reduced by $23 \%$ by using this mixture as an insulation panel. this will allow us to valorise this plant as a bio-sourced material.

\section{Conclusion}

In this article, we have studied the impact of using Typha Australis in a habitat. This study was carried out using clay as a binder and taking conventional buildings with the same characteristics to compare the rate of air conditioning use.

The result allowed us to evaluate the impact of this mixture on a building, because by substituting the cement mortar of the conventional building with the mixture of clay and Typha Australis, the rate of energy requirement decreased by $23 \%$ year-round, which is a satisfactory rate

In perspective, we can consider changing the position of this insulation panel in order to better evaluate this optimization.

\section{References}

1. Y.BROUARD. Thèse de Doctorat, Université Tours, (2018)

N.Dujardin, D.Thevenot. (25 $5^{\text {ème }}$ Journées Scientifques de l'Environnement - L'économie verte en question, 2014)

M. Lamrani, N. Laaroussi, A. Khabbazi, M. Khalfaoui, M. Garoum, A. Feiz, cas stu in con mat 7, (2017)

A. El Bakkouri, Thèse de Doctorat en Sciences, Faculté des sciences Tétouan Maroc (2004).

A. Khabbazi, M. Garoum, O. Terahmina, AMSE, Jou.Adv.Of.mode.and.Sim 74,(2015)

Y. Dieye, V.Sambou, M.Faye, A.Thiam, M.Adj,D.Azilinon, Jou of Buil Eng 9,(2017)

M.T.Diatta,S.Gaye,A.Thiam,D.Azilinon, Cong. SFT, Perpignan (2011)
S. Klei, A Transient System Simulation Program, Solar Energy Laboratory, (University of Wisconsin-Madison, Madison,WI, USA ,2000)

TRNSYS 17, Upgrade Description

B. Berges,, (Thèse de Doctorat, Université de Nice, 1986)

M. Annabi, A Mokhtari, TA Hafrad Rev des Ene Ren, 9 (2006) 